International Journal of Instruction e-ISSN: 1308-1470 • www.e-iji.net

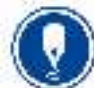

April 2021 • Vol.14, No.2

p-ISSN: 1694-609X

pp. 461-482

Article submission code:

20200422113154

Received: 22/04/2020

Revision: 27/09/2020

Accepted: 20/10/2020

OnlineFirst: 26/01/2021

\title{
The Compatibility of Developed Mathematics Textbook Content in Saudi Arabia with NCTM Standards: A Critical Review
}

\section{Mansour Saleh Alabdulaziz}

Asst. Prof., Department of Curriculum and Instruction, Imam Abdulrahman Bin Faisal University, Saudi Arabia, malabdulaziz@iau.edu.sa

\section{Steve Higgins}

Prof., School of Education, Durham University, United Kingdom, s.e.higgins@durham.ac.uk

The purpose of this critical review is to explore international perspectives on the analysis of the content of developed mathematics textbooks. This led us to explore the contributions to our knowledge of the compatibility of the content of the developed mathematics textbooks in the Kingdom of Saudi Arabia (KSA) with the standards of the National Council of Teachers of Mathematics (NCTM) in the United States of America (USA) between 2013 and 2019. This study sought to extract and synthesise the recommendations subsequent to comparing them according to the methodology, samples, grades, the number of NCTM standards that were covered, and the results of the analyses. Moreover, this review sought to identify the areas of the mathematics curriculum which covered a low percentage of NCTM standards according to such studies, and to help the stakeholders to develop these curricula. It was recommended that a study should be conducted in order to evaluate the content of developed mathematics for grades not covered in their studies, such as primary grades 1 to 2 and secondary grades 2 to 3 . We found that the mathematics curriculum for the first secondary grade achieved a low percentage of NCTM standards.

Keywords: NCTM standards, developed curriculum, mathematics textbooks, critical review, mathematics

\section{INTRODUCTION}

Textbooks are regarded as a principal and essential information source; indeed, in certain situations, they are the only means of providing the student with subject matter (Alzubi \& Alobeidan, 2014; Keith, 1991). The mathematics textbooks serve as the principal organizer of mathematical skills which we expect students to learn (Chiappetta \& Fillman, 2007), as well as the principal resource for teachers (Alzubi \& Alobeidan, 2014; Jitendra et al., 2010; Mrayyan, 2013). Furthermore, according to Schmidt et al., (2002), student learning is influenced by the content of mathematics textbooks, as well

Citation: Alabdulaziz, M. S., \& Higgins, S. (2021). The Compatibility of Developed Mathematics Textbook Content in Saudi Arabia with NCTM Standards: A Critical Review. International Journal of Instruction, 14(2), 461-482. https://doi.org/10.29333/iji.2021.14226a 
as instructional practice. Textbooks are undoubtedly essential to learning and teaching, especially in the field of mathematics.

Ongoing advances in various domains of education in the KSA in conjunction with the Ministry of Education's desire to implement a novel and realistic paradigm in teaching and learning have stimulated numerous developments in and amendments to mathematics and science curricula (Saeed, Abdul Hamid, \& Alshalhoub, 2011). Indeed, specific changes in the development of mathematics curricula have formed part of this overall project (Alshehri \& Ali, 2016).

Advances in the teaching and learning of mathematics have been driven by the changes that have taken place in global standards from the 1980s onwards (Obaid, 2010). For instance, the document on mathematics standards published by the National Council of Teachers of Mathematics (NCTM) in 1989 and then reissued in 2000, explained precisely what constitutes the fundamentals of contemporary mathematics education and stated that this should be applied to all students while allowing them to exhibit their differing capabilities. Thus, it is important to be mindful of students' disparate needs, interests, and achievements in mathematics. All students, however, are entitled to receive high level mathematical instruction (Abbas \& Alabsi, 2007).

In the past, several researchers have investigated mathematics projects according to NCTM standards (Ardisana, 2006; Blackwell, 2001; Heitmann, 2006; Jitendra et al., 2010; Wood, 2006). Such researchers discovered a positive relationship between students' learning outcomes as well as their achievement in mathematics on the basis of how textbooks were designed in order to comply with NCTM standards. It has been established that such standards have enhanced the results of student learning in this subject. Furthermore, these standards helped in increasing student achievements in their knowledge and skills in mathematics, addressing the issue of lower-level mathematics students, and enhancing teachers' professional growth and that of educational leaders. For instance, Jitendra et al. (2010) conducted a case study examining the impact of the prospective textbook and the implemented curricula (teachers' instructional practice) compliance with the NCTM standards on mathematics results in one elementary school involving four classrooms. Teacher compliance and textbooks to the standards were evaluated by applying content analysis as well as by direct observation procedures, respectively. They found a connection between further NCTM standards being applied to enhance student achievement and attitude towards mathematics.

It is clear from previous that assessing mathematics textbooks content in the light of the NCTM standards represents an important pillar in the development of the teaching and learning of mathematics. Hence, the problem of current research arises to study the compatibility of the content of developed mathematics textbooks in the KSA with the standards of NCTM between 2013 and 2019. This is in order to help the stakeholders in the KSA to develop these curricula according to the NCTM standards in mathematics textbooks. 


\section{Significance of the study}

International studies have demonstrated that textbooks are very important tools that affect the students' performance in the classrooms (Fujita \& Jones, 2003; Valverde et al., 2002). The Saudi Ministry of Education made its decision to develop the mathematics curriculum based on international experiences which have proved effective in improving education. The movement of global standards that have emerged since the 1980 s is one fundamental of mathematics teaching and learning development (Obaid, 2010), such as NCTM standards. Therefore, the overall purpose of this critical review was to explore international perspectives on the analysis of the content of developed mathematics textbooks. In addition, examining current research findings in an attempt to identify contributions to our knowledge of the compatibility of the content of the developed mathematics textbooks in the KSA with the NCTM standards between 2013 and 2019. This study sought to extract and synthesise the recommendations subsequent to comparing them according to the methodology, samples, grades, the number of NCTM standards that were covered, and the results of the analyses. Moreover, this review sought to identify the areas of the mathematics curriculum which covered a low percentage of NCTM standards according to such studies, and to help the stakeholders to develop these curricula.

\section{LITERATURE REVIEW}

This section attempts to review the relevant literature and research related to the compatibility of the content of developed mathematics textbooks in the KSA with the NCTM standards. The first theme presents a general overview of the KSA and the education in order to inform the readers about the country and its educational system. The second theme provides the KSA Vision 2030 and the mathematics curriculum, the importance of this section being to give the reader an idea of how this vision relates to NCTM standards. The third theme presents "textbooks in mathematics education: from an international perspective". The fourth theme presents theoretical frameworks for this study, including the NCTM standards. This is followed by a review of the relevant literature and research related to the compatibility of the content of the mathematics textbook in the KSA with the NCTM.

\section{General overview of the KSA and the education}

The KSA lies at the furthest part of south-western Asia. Riyadh is the capital of the KSA, and located in the centre of the country. The kingdom comprises 13 administrative regions, each of which is divided into governorates.

The education system in the KSA usually has four stages (pre- primary, primary, middle and secondary). The children are taught at pre- primary for the duration of two years. Primary schools usually have six grades (years 1 to 6 ), equivalent to grades 1 to 6 . Middle schools usually have three grades (years 1,2 and 3) equivalent to first, second and third grades. Furthermore, secondary schools usually have three grades (years 1,2 and 3) equivalent to first, second and third grades. This means that schooling from primary to secondary lasts for 12 years. Children may attend kindergartens as parents wish; however, at the age of six, they must enter a primary school. 
In regard to textbooks, the government provides textbooks to public and private schools free of charge. It is compulsory that private schools use the same textbooks and curricula employed in the public school, and the international schools have their own curricula depend on the country they came from. Textbooks are the core of the curriculum and syllabus in all classrooms in KSA. The developed mathematics curriculum was written in group of books (student textbook, exercise book, teacher guidebook, assessment book, learning resources book). All students must obtain student textbook and exercise book; and teachers must obtain teacher guidebook, assessment book and learning resources book which should be used as described in teacher guidebook. This mean mathematics textbook usage is compulsory in KSA.

\section{THE SAUDI VISION 2030 AND MATHEMATICS CURRICULUM}

Saudi Arabia's Vision 2030 project was launched by Prince Mohammed bin Salman Al Saud, crown prince, who is chairman of the Council of Economic and Development Affairs, on 25 April 2016. This extensive programme will guide the nation towards economic diversification. The Vision involves the following three basic targets: a strong economy, a dynamic society and an enterprising country. Although the principal focus of Vision 2030 is in the direction of several business investment enterprises, cultural programmes and economic reforms, it is impossible to introduce such programmes without there being quality education.

Includes developing an up-to-date curriculum concentrating upon high literacy and numeracy standards as well as character development and abilities. In addition to keeping a record of progress, this will publish a highly-developed scope of educational results which demonstrate annual enhancements (Saudi Arabia's Vision for 2030, 2017). It will consequently supply everyone with exceptional learning opportunities. These will enhance learning results and quality in order to motivate creation and innovation. They will also upgrade the employees' educational abilities and skills as well as developing the curriculum (Saudi Arabia's Vision for 2030, 2017). The principal resource for attaining educational objectives is the curriculum. These objectives include enabling people to obtain qualifications which would be advantageous to themselves. They would also accept responsibility and attain extensive development in their societies which would also benefit (Abdul Salam, 2006).

Also, another aim of the KSA vision is to develop an education system which is able to manage market requirements, thereby constructing a successful economy (Saudi Arabia's Vision for 2030, 2017). The way in which education contributes to the KSA economy needs to be understood (Alzahrani, 2017). We are aware that mathematics forms the basis of science and technology, meaning that the level of economic and social development has a close association with that of the mathematical sciences (Kuku, 2012). Additionally, the production of technicians and technologists in any society is dependent upon the level of the study of mathematics in that society. Therefore, it has been claimed that the gap between the standard of teaching and learning mathematics leads to the gap in the development progress between developing nations and advanced nations (Ukeje, 2002). There is a gap between the skills which students acquire and the 
current necessities of life and work. Education ought to be reconstructed in order to satisfy the goals of Vision 2030 (Almaimooni, 2016).

\section{TEXTBOOKS IN MATHEMATICS EDUCATION: FROM AN INTERNATIONAL PERSPECTIVE}

It is essential to learn mathematics as it is a skill utilised in almost every aspect of our lives $(\mathrm{Li}, 1999)$. In the majority of countries, teachers and students express a preference for the use of mathematics textbooks (Haggarty \& Pepin, 2002; Johansson, 2003; Pepin, 2001). For instance, the usage of textbooks is mandatory in Mexico (Santos et al., 2006) and has reached $75-90 \%$ in the USA (Tyson \& Woodward, 1989) and almost $99 \%$ in Finland (Törnroos, 2004).

Teachers prefer to use mathematics textbooks because it assists them in organising a class, constructing a daily teaching plan, and choosing activities for students (Ball \& Feiman-Nemser, 1988; Freeman \& Porter, 1989; Johansson, 2003, 2005; Pepin, 2001; Santos et al., 2006; Schmidt et al., 2001). For instance, when devising their teaching plans they can draw on the textbooks to help them decide which topics to teach and in what order (Freeman \& Porter, 1989; Johansson, 2005; Nicol \& Crespo, 2006; Pepin, 2001). Indeed, Reys et al. (2004) found that because American textbooks cover a multitude of topics and revisit material taught previously, teachers find it extremely hard to plan their teaching without them.

Besides, students prefer to use textbooks when doing their homework because it enables them to review on what they have learned (Reys et al., 2004; Tyson \& Woodward, 1989). Several international comparative studies have demonstrated the significant impact textbooks have on students' achievement. This has inspired a large number of researchers to examine this relationship further (Fujita \& Jones, 2003; Ginsburg \& Leinwand, 2005; Haggarty \& Pepin, 2002; Johansson, 2003; Li, 2000; Stevenson, 1985; Valverde et al., 2002; Zhu \& Fan, 2004).

For instance, a key purpose of mathematics education is to enhance students' problem solving abilities. Consequently, it may be helpful to analyse textbooks, with regard to their adequacy in the development of problem-solving abilities (Olkun \& Toluk, 2002). Indeed, it has been suggested that the deficiency of some textbooks in this regard may be responsible for the differences students exhibit in terms of their ability to solve problems $(\mathrm{Li}, 2000)$. Consequently, the effect of mathematical problems presented in textbooks on mathematical achievement has been explored by several researchers $(\mathrm{Li}$, 2000; Lo et al., 2001; Mayer et al., 1995; Stigler et al., 1986).

Several countries have strived to establish why the performance of their students at the required level has been sub-optimal. They wanted to know why students in other countries performed much better in mathematics. Thus, a series of comparison studies were conducted to reveal the reasons for this divergence in achievement between students from different countries (Ginsburg \& Leinwand, 2005; Haggarty \& Pepin, 2002; Lo et al., 2001; Mayer et al., 1995). 
International studies have indicated that performance in classrooms is strongly affected by textbooks (Fujita \& Jones, 2003; Valverde et al., 2002). Although Freeman and Porter (1989) identified minimal effect on teaching and learning, other scholars have sought to determine the nature of this effect on mathematical achievement by exploring differences and similarities between textbooks in countries where levels of mathematical achievement differ (Haggarty \& Pepin, 2002; Li, 1999, 2000; Mayer et al., 1995; Zhu \& Fan, 2004).

Foxman (1999) found that students who made use of textbooks in classrooms achieved superior scores in the Trends in International Mathematics and Science Study (TIMSS). Similarly, Yeap (2005) found that textbooks increased levels of mathematics achievement among Singaporean students as measured by TIMMS scores. Moreover, he asserted that students were more likely to acquire a strong foundation in mathematics and exhibit increased levels of creativity when textbooks contained a high number of visual representations, and problems to be solved.

In the USA, the thoughts and opinions of teachers, administrations, and parents are drawn on by each district to help them choose which textbooks to use, when topics will be aught, and how they will be taught. However, a general curriculum framework developed by the NCTM means that virtually all textbooks in the USA conform NCTM standards. Thus, although different textbooks are used, all students are afforded an equal opportunity to learn (Reys et al., 2004).

Give the importance of learning mathematics in people's everyday lives, the findings of cross-national research on mathematics education need to be scrutinised closely and to form the basis of essential reforms in mathematics education ( $\mathrm{Li}, 1999)$. To that end, several of these studies have performed a content analyses of textbooks (Törnroos, 2005; Schmidt et al., 1997).

\section{NCTM AND PRINCIPLES AND STANDARDS FOR SCHOOL MATHEMATICS}

The NCTM, inaugurated in 1920, is an international organization supporting mathematics teaching and learning for pre-kindergarten to Grade 12 pupils. It originated from an outgrowth of the Chicago Mathematics Club. Furthermore, over a period of time, the NCTM has published numerous documents for the purpose of guiding $\mathrm{K}-12$ mathematics education.

The NCTM presented the first contemporary series of subject matter standards in the USA in 1989. Subsequently, in 2000, it was upgraded and extended when the NCTM produced Principles and Standards for School Mathematics. This document is now the grounding for state and local mathematics curriculum standards in the USA. Moreover, it includes a series of six principles which form the basis for the document's recommendations, and 10 standards which basically describe the mathematical skills required by pupils annually through to Grade 12 (NCTM, 2000).

According to Mundy (2000), the NCTM's target is "to provide the vision and leadership necessary to ensure a mathematics education of the highest quality for all students" (p. 868). Such standards are extensively applied in the K-12 community as a result of its 
significance to mathematics teaching and learning (Ardisana, 2006; Blackwell, 2001; Heitmann, 2006; Wood, 2006).

The NCTM has two standards' classifications (NCTM, 2000): content standards, describing the mathematical content which students ought to learn at each grade level; and process standards, which concentrate on various techniques which students use to obtain, comprehend, and use the content. The NCTM determines various techniques such as: (1) problem solving, (2) reasoning and proof, (3) communication, (4) connections, and (5) representation. The following are the five content standards: (1) number and operations, (2) algebra, (3) geometry, (4) measurement, and (5) data analysis and probability.

Definitions of the five domains of content standards (NCTM, 2000) are given below. The subcategories of each standard comprise what the NCTM regards as expected skills for pupils of this age:

-Number and operations standard: Pupils ought to be capable of: (1) understanding numbers and methods of representing them, relationships between numbers and number systems; (2) understanding what operations mean and how they relate to one another; and (3) calculating fluently and providing reasonable approximations.

-Algebra standard: Pupils ought to be capable of: (1) understanding patterns, relationships and functions; (2) representing and analysing mathematical situations and structures by applying algebraic symbols; and (3) applying mathematical paradigms to represent and comprehend quantitative relationships.

-Geometry standard: Pupils should be able to: (1) analyse the attributes of two- and three-dimensional geometrical shapes, and develop mathematical arguments regarding geometrical relationships; (2) specify locations and define spatial relationships by using coordinate geometry and other representational methods; (3) use transformations and symmetry to analyse mathematical situations; and (4) apply visualisation, spatial reasoning, and geometrical modelling to resolve problems.

-Measurement standard: Pupils ought to be capable of: (1) understanding measurable properties of objects and the units, systems, and measurement procedures; and (2) using suitable methods, tools, and formulae to establish measurements.

- Data analysis and probability standard: Pupils should be able to: (1) prepare questions which can be addressed with data; (2) gather, arrange and display appropriate data to answer such questions; and (3) comprehend and use fundamental probability concepts.

THE EVALUATION OF DEVELOPED MATHEMATICS TEXTBOOKS' CONTENT ACCORDING TO NCTM

The evaluation of mathematics textbooks' content, according to NCTM standards, has been addressed by many researchers (Albalawi, 2019; Altamimi, 2017; Alshehri \& Ali, 2016; Alshehri, 2015; Alzubi \& Alobeidan, 2014; Hasanen \& Alshehri, 2013). For instance, Albalawi (2019) examined the compatibility of the Grade 6 mathematics textbook contents in the KSA with the NCTM standards. The researcher used the 
analytical descriptive technique to attain this target. This intentional sample, which represents the study population, is composed of the first and second parts of the mathematics textbook as well as the two exercises books. The researcher used an analysis card to gather the study data. The tool containing the process and content standards. Subsequently, the researcher applied this to confirm the validity and validity of the analysis. The study results demonstrate the compatibility content of the Grade 6 mathematics textbook with the standards of the content areas as follows: number and operations standards $(47.63 \%)$, algebra standards (17.72\%), measurement standards (14.54\%), the standards of data analysis and mathematical probability (11.31\%), and the engineering standards (8.81\%). The content of the Grade 6 mathematics textbook in the KSA is compatible with the process areas' standards as follows: percentage of representation standards $(31,17 \%)$, connections standards $(25.84 \%)$, communication standards (24.83\%), reasoning and proofing standards $(9.45 \%)$, and that of problem solving standards $(8.72 \%)$. The researcher recommended the necessity to develop standards with low percentages.

Altamimi (2017), in his study, aimed to analyse the mathematics book content for the third grade of the middle stage in the KSA with the international standards for operations and content (NCTM, 2000). The study population consists of the mathematics book for third-grade students, and the study sample represents the same study population; furthermore, in order to answer the three questions of the study, the researcher has developed a tool comprising two models. The first model analyses the book and includes the key indicators for the global standards of the process (NCTM, 2000) (problem-solving, mathematical connections, mathematical communication, mathematical representation and mathematical thinking) in the mathematics book for the third grade of the middle stage in the KSA. The second model analyses the book, including the key indicators for the global standards of the content (NCTM, 2000) (in number and operations, algebra, geometry, measurement, data analysis, and probability). The results of the study have shown that the book included standards such as: problemsolving, mathematical connections, mathematical communication, mathematical thinking, and mathematical representation with high consistency regarding the standard of mathematical connections with the average degree. The results of content analysis in the standards shown (number and operations, algebra, geometry, measurement, and data analysis and probability) were highly consistent. Furthermore, the results showed a clear contrast between the content analysis results and estimates of the sample of the study. This is according to the degree of availability of global standards in the third-grade mathematics book at the middle stage in the KSA. It showed the results of the content analysis and the high degree of availability, whereas the study also showed estimates of the study sample with a medium degree of availability, except for the standard of mathematical connections in which the content analysis results agreed with estimates of the sample members on the medium degree of availability of this standard. In the light of these findings, the researcher recommends the need to keep up to date with developments in caring for global standards and seeking to achieve quality in the educational process. 
Alshehri and Ali (2016) explored the compatibility of the content of developed mathematics textbooks' (grades 6 to 8) in the KSA with NCTM standards in the following areas: number and operations, algebra, geometry, measurement, data analysis and probability. In order to attain this target, the list of NCTM standards for grades 6 to 8 were translated into Arabic; furthermore, a content analysis card was produced according to the standards list for mathematics textbooks for the academic year 14341435 AH / 2013-2014 CE. The results of the study demonstrated that the content of developed (grades 6 to 8) mathematics textbooks is $96.3 \%$ compatible with NCTM standards, because the content is expected to be 52 from the standards list, whereas, the anticipated 3.7\% from the NCTM standards expectations list was not attained in these five areas.

Alshehri (2015) sought to evaluate the first secondary developed mathematics textbook content in KSA according to NCTM standards. The descriptive analytical method was used in order to achieve this goal and numbers and operations topics were analysed by the tool of content, which have has built to NCTM standards. The study sample comprises numbers and operations topics. The results showed that the realisation of NCTM standards in the first secondary developed mathematics textbook content is very low, where the percentage does not exceed 13, which is unacceptable in the educational field. Consequently, the searcher provided some recommendations and suggestions.

Alzubi and Alobeidan (2014) aimed to investigate the extent to which the fourth grade developed mathematics textbook in the KSA included the NCTM standards. The population and study sample comprised a mathematics textbook which has been studied for the fourth grade in the KSA since 2009. A tool has been built for analysis, as well as to ensure its validity and stability. After conducting the analysis, the study results of showed that the content of the mathematics book for the fourth grade includes the following percentages: number and operations $(2.03 \%-14.57 \%)$, geometry $(6.42 \%-$ $13.58 \%)$, data analysis and probability $(6.98 \%-15.12 \%)$, problem-solving $(9.41 \%$ $28.24 \%)$, reasoning and proof $(5.17 \%-15.52 \%)$ and communication $(4.30 \%-25.81 \%)$. The study recommended the need to conduct more studies on the standards of the American National Council of Mathematics Teachers and the extent to which books consider these standards because of their importance, also considering other variables such as middle and high-school books.

Moreover, Hasanen and Alshehri (2013) conducted a study with the intention of exploring the compatibility of the content of developed mathematics textbooks for grades 3 to 5 in the KSA with NCTM standards, particularly in the topics of number and operations, algebra, geometry, measurement, data analysis and probability. In order to attain this objective, a list of NCTM mathematics textbooks content (grades 3 to 5) standards was produced, and subsequently translated, and also a content analysis card of developed mathematics textbooks for grades 3 to 5 was prepared for the academic year 1432-1433/ 2011-2012 CE according to the standards list. The outcome revealed that the developed mathematics textbooks (grades 3 to 5) content in the KSA is $93.7 \%$ compatible with NCTM standards, with the developed mathematics textbooks content 
achieves (59) being indicators of these standards, whereas the content failed to attain (4) the indicators by $6.3 \%$ in the five areas.

\section{METHODS}

\section{Search and Retrieval of Studies}

The current literature review implements a systematic approach to analyse critically of the compatibility of the content of the developed mathematics textbooks for grades (third to sixth "primary stage" - first to third "middle stage", first "secondary stage") in the KSA with NCTM between 2013 and 2019. Systematic literature review can be defined as "a scientific process governed by a set of explicit and demanding rules oriented towards demonstrating comprehensiveness, immunity from bias, and transparency and accountability of technique and execution" (Dixon-Woods, 2010, p.332). The process of systematic review is characterized by some criteria that are used to narrow the scope of a review (Higgins \& Green, 2009). These criteria are the standards for judging the weight of evidence in the studies included in this review. Table. 1 explains the inclusion criteria in detail.

Table. 1

Literature inclusion criteria

\begin{tabular}{ll}
\hline Criteria & Description \\
\hline Topic & $\begin{array}{l}\text { The primary inclusion criterion was that the study should focus on the compatibility } \\
\text { of the content of the developed mathematics textbooks in the KSA with NCTM. }\end{array}$ \\
\hline Period & We found studies only from 2013 to 2019. \\
\hline Research Base & Literature should include only Saudi mathematics textbooks. \\
\hline $\begin{array}{l}\text { Reliability \& } \\
\text { Validity: }\end{array}$ & $\begin{array}{l}\text { The outcomes of literature studies must be valid and reliable according to the type of } \\
\text { the study and publication indexed. }\end{array}$ \\
\hline Research questions & A coding scheme was developed in relation to the research questions. \\
\hline
\end{tabular}

A preliminary search indicated that little research has been conducted on the compatibility of the content of the developed mathematics textbooks in the KSA with NCTM. Although we attempted to find additional studies relating to textbooks we found studies only from 2013 to 2019 . Therefore, a date range of approximately seven years between 2013 and 2019 was chosen to represent research in the compatibility of the content of the developed mathematics textbooks with NCTM which was conducted after 13 years of the implementation of the NCTM (2000).

Extensive searches were conducted in key full-text databases, including Education Full Text, Educational Resources Information Center (ERIC), Wiley Interscience, Journal Storage (JSTOR), and Dar Almandumah with the keywords in varying combinations: compatibility, NCTM standards, developed curriculum, mathematics textbooks, and the KSA.

These keywords were identified through evaluation of abstracts, and suggested further searches generated by the initial literature scan. We found 20 articles; however, studies were screened for inclusion by reading the title and abstract, then included studies at this stage were read to ensure they met the inclusion criteria. 
A coding scheme was developed in relation to the research questions and each of the included studies was reviewed and summarized in relation to the aims of the study, the recommendations and the coverage of NCTM standards. Therefore, as we mentioned above that only, seven studies matched the inclusion criteria of the current review.

\section{Research Questions}

1- Why did the researchers analyze the content of mathematics textbooks?

2- What are the recommendations extracted from these studies after comparing them according to the methodology, samples, grades, the number of NCTM standards that were applied, and the result?

3- What percentage of NCTM standards are covered by the mathematics curriculum covered by the textbooks according to these studies?

\section{FINDINGS AND DISCUSSION}

With respect to the first question, textbooks are clearly essential tools in teaching and learning mathematics. Teachers use them to construct daily teaching plans, organise classes, and as a source of, exercises, activities, homework, and illustrative examples (Ball \& Feiman-Nemser, 1988; Freeman \& Porter, 1989; Johansson, 2003, 2005; Pepin, 2001; Santos et al., 2006; Schmidt et al., 2001). Besides, students make use of textbooks to review what they have learned, to seek answers to questions, to complete coursework, increase their understanding of mathematical concepts, and carry out the tasks and exercises set by the teacher. Several international studies have explored the effect of textbooks on achievement in mathematics by comparing and analysing the content of textbooks used in different countries (Fujita \& Jones, 2003; Ginsburg \& Leinwand, 2005; Haggarty \& Pepin, 2002; Johansson, 2003; Li, 2000; Stevenson, 1985; Valverde et al., 2002; Zhu \& Fan, 2004). However, differences in mathematical achievement among students from different countries have been found to be caused by variations in the opportunities textbooks provide to learn mathematics. The NCTM employs two classifications of standards (NCTM, 2000): content standards and process standards, as indicators of opportunities to learn. Thus, it is important for textbook writers to take these standards into consideration.

Therefore, we need to move to the second research question to know the possible recommendations extracted from these studies after comparing them according to the methodology, samples, grades, the number of NCTM standards that were applied, and the result. The following Table shows summary of the studies that were used in this study. 
Table 2

Summary of the studies

\begin{tabular}{|c|c|c|c|c|c|c|}
\hline The study & The aim & The grade & The method & The area & The results & The recommendations \\
\hline $\begin{array}{l}\text { Albalawi } \\
\text { (2019) }\end{array}$ & $\begin{array}{l}\text { All studies } \\
\text { have } \\
\text { investigated } \\
\text { the extent to } \\
\text { which } \\
\text { developed } \\
\text { mathematics } \\
\text { textbooks in } \\
\text { Saudi Arabia } \\
\text { were } \\
\text { compatible } \\
\text { with NCTM } \\
\text { standards. }\end{array}$ & $\begin{array}{l}\text { Sixth } \\
\text { grade } \\
\text { (Primary } \\
\text { stage) }\end{array}$ & $\begin{array}{l}\text { The } \\
\text { analytical } \\
\text { descriptive } \\
\text { method. }\end{array}$ & $\begin{array}{l}\text { They covered all } \\
\text { NCTM }(2000) \\
\text { standards. }\end{array}$ & $\begin{array}{l}\text { Operational standards is } \\
47.63 \% \text {, algebra standards } \\
17.72 \% \text {, and measurement } \\
\text { standards } 14.54 \% \text {. Data } \\
\text { analysis and mathematical } \\
\text { probability is } 25.84 \% \text {, and } \\
\text { engineering standards is } \\
8.11 \% \text {. Standards } \\
\text { representation is } 31.17 \% \text {, } \\
\text { and communication } \\
\text { standards is } 24.83 \% \text {. } \\
\text { Reasoning and proofing } \\
\text { standards is } 9.45 \% \text {, and } \\
\text { problem-solving standards } \\
\text { is } 8.72 \% \text {. }\end{array}$ & $\begin{array}{l}\text { 1- The researcher recommends } \\
\text { the importance of developing } \\
\text { standards with low } \\
\text { percentages, particularly the } \\
\text { engineering standards, } \\
\text { problem- solving standards and } \\
\text { reasoning and proofing } \\
\text { standards. } \\
\text { 2- Conducting similar studies to } \\
\text { reveal the availability of } \\
\text { NCTM standards in } \\
\text { mathematics books for middle } \\
\text { and high school. }\end{array}$ \\
\hline $\begin{array}{l}\text { Altamimi } \\
(2017)\end{array}$ & & $\begin{array}{l}\text { Third } \\
\text { grade of } \\
\text { the } \\
\text { middle } \\
\text { stage }\end{array}$ & & $\begin{array}{l}\text { He covered all } \\
\text { NCTM (2000) } \\
\text { standards. }\end{array}$ & $\begin{array}{l}\text { Study results have shown } \\
\text { that the book included } \\
\text { standards (mathematical } \\
\text { problem-solving, and } \\
\text { mathematical } \\
\text { communication, } \\
\text { mathematical thinking, } \\
\text { and mathematical } \\
\text { representation) with high } \\
\text { consistency, and in terms } \\
\text { of standard mathematical } \\
\text { connections, the degree of } \\
\text { consistency of the } \\
\text { average; additionally, the } \\
\text { results of content analysis } \\
\text { in the standards shown } \\
\text { (number and operations } \\
\text { algebra, geometry, } \\
\text { measurement, and data } \\
\text { analysis and probability) } \\
\text { were highly consistent. }\end{array}$ & $\begin{array}{l}\text { 1- The researcher } \\
\text { recommended the need to keep } \\
\text { pace with developments in the } \\
\text { interest of global standards and } \\
\text { applied to achieve quality in the } \\
\text { educational process. } \\
\text { 2- Conducting similar studies to } \\
\text { reveal the availability of } \\
\text { NCTM standards in } \\
\text { mathematics books for different } \\
\text { levels. }\end{array}$ \\
\hline $\begin{array}{l}\text { Alshehri } \\
\text { \& Ali } \\
\text { (2016) }\end{array}$ & & $\begin{array}{l}\text { Grades 6- } \\
8 \text { for } \\
\text { primary } \\
\text { and } \\
\text { middle } \\
\text { stages }\end{array}$ & & $\begin{array}{l}\text { The study was } \\
\text { limited to five } \\
\text { areas of NCTM } \\
\text { (2000) which } \\
\text { are number and } \\
\text { operations, } \\
\text { algebra, } \\
\text { geometry, } \\
\text { measurement, } \\
\text { and data } \\
\text { analysis and } \\
\text { probability. }\end{array}$ & $\begin{array}{l}\text { The study outcome } \\
\text { showed that the content of } \\
\text { grades } 6 \text { to } 8 \text { developed } \\
\text { mathematics textbooks is } \\
96.3 \% \text { compatible with } \\
\text { NCTM standards, } \\
\text { because the } 52 \\
\text { expectations are } \\
\text { anticipated from the } \\
\text { standards list. Also } 3.7 \% \\
\text { from the NCTM standards } \\
\text { expectations list was not } \\
\text { attained in these five } \\
\text { areas. }\end{array}$ & $\begin{array}{l}\text { 1- They recommend achieving } \\
\text { the standards expectations } \\
\text { incompletely covered in the } \\
\text { area of number and operations } \\
\text { to fulfil complete compatibility, } \\
\text { and to enhance teacher training } \\
\text { to teach the newly- developed } \\
\text { curriculum appropriately in } \\
\text { order to achieve global } \\
\text { standards of quality in the } \\
\text { educational process. } \\
2 \text { - Conducting similar studies } \\
\text { for grades } 9 \text { to } 12 \text {. }\end{array}$ \\
\hline $\begin{array}{l}\text { Alshehri } \\
\text { (2015) }\end{array}$ & & $\begin{array}{l}\text { First } \\
\text { secondary }\end{array}$ & & $\begin{array}{l}\text { The study } \\
\text { covered only } \\
\text { one area, } \\
\text { namely, number } \\
\text { and operations. }\end{array}$ & $\begin{array}{l}\text { The results showed that } \\
\text { the realisation of NCTM } \\
\text { standards in the first } \\
\text { secondary developed } \\
\text { mathematics textbook } \\
\text { content is very low, and } \\
\text { that the percentage does } \\
\text { not exceed } 13 \text { which is }\end{array}$ & $\begin{array}{l}\text { 1- Based on scientific bases } \\
\text { and international standards } \\
\text { when building topics of } \\
\text { numbers and operations. } \\
\text { 2- Development of mathematics } \\
\text { curricula to satisfy the } \\
\text { standards of school } \\
\text { mathematics (NCTM), }\end{array}$ \\
\hline
\end{tabular}

International Journal of Instruction, April 2021 •Vol.14, No.2 


\begin{tabular}{|c|c|c|c|c|}
\hline & & & $\begin{array}{l}\text { unacceptable in the } \\
\text { pedagogical field. }\end{array}$ & $\begin{array}{l}\text { considering the standard of } \\
\text { numbers and operations. } \\
\text { 3- This study could be } \\
\text { replicated and extended to } \\
\text { include other grades. }\end{array}$ \\
\hline $\begin{array}{l}\text { Alzubi \& } \\
\text { Alobeidn } \\
\text { (2014) }\end{array}$ & 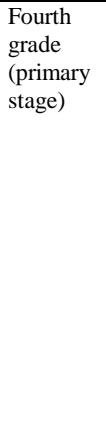 & $\begin{array}{l}\text { The study } \\
\text { covered all six } \\
\text { areas involving } \\
\text { number and } \\
\text { operations, } \\
\text { geometry, data } \\
\text { analysis and } \\
\text { probability, } \\
\text { problem- } \\
\text { solving, } \\
\text { reasoning and } \\
\text { proof, and } \\
\text { communication. }\end{array}$ & $\begin{array}{l}\text { The results of the study } \\
\text { revealed that the fourth } \\
\text { grade mathematics } \\
\text { textbook includes the } \\
\text { following: numbers and } \\
\text { the common operations } \\
(2.03 \% \text { - } 14.57 \%) \text {, } \\
\text { geometry (6.42 - } \\
13.58 \%) \text {, probability and } \\
\text { analysis features (6.98\% - } \\
15.12 \%) \text {, problem solving } \\
(9.41 \%-28.24 \%) \text {, } \\
\text { thinking and reasoning } \\
(5.17 \% \text { - } 15.52 \%) \text {, } \\
\text { communication }(4.30 \% \text { - } \\
25.81 \%) \text {. }\end{array}$ & $\begin{array}{l}\text { The study recommended } \\
\text { conducting more studies } \\
\text { concerning the American } \\
\text { Council for Mathematics, with } \\
\text { teachers taking those standards } \\
\text { into consideration and also } \\
\text { involving other variables such } \\
\text { as other textbooks of the } \\
\text { preparatory and secondary } \\
\text { stages. }\end{array}$ \\
\hline $\begin{array}{l}\text { Hasanen } \\
\& \\
\text { Alshehri } \\
(2013)\end{array}$ & $\begin{array}{l}\text { Grades } 3 \\
\text { to } 5 \\
\text { (primary } \\
\text { stage) }\end{array}$ & $\begin{array}{l}\text { The study was } \\
\text { limited to these } \\
\text { five areas: } \\
\text { number and } \\
\text { operations, } \\
\text { algebra, } \\
\text { geometry, } \\
\text { measurement, } \\
\text { and data } \\
\text { analysis and } \\
\text { probability. }\end{array}$ & $\begin{array}{l}\text { The results showed that } \\
\text { the developed } \\
\text { mathematics textbooks } \\
\text { content for grades } 3 \text { to } 5 \\
\text { in Saudi Arabia is } 93.7 \% \\
\text { compatible with NCTM } \\
\text { standards, the developed } \\
\text { mathematics textbooks } \\
\text { content achieves (59) } \\
\text { indicators of NCTM } \\
\text { standards, while the } \\
\text { content failed to achieve } \\
\text { (4) indicators by } 6.3 \% \text { in } \\
\text { the five areas. }\end{array}$ & $\begin{array}{l}\text { 1- They recommended } \\
\text { achieving the standards } \\
\text { incompletely covered. } \\
\text { 2- Conducting similar studies } \\
\text { for grades } 6 \text { to } 8 \text { and } 9 \text { to } 12 \text {. }\end{array}$ \\
\hline
\end{tabular}

The aforementioned studies (Albalawi, 2019; Altamimi, 2017; Alshehri \& Ali, 2016; Alshehri, 2015; Alzubi \& Alobeidan, 2014; Hasanen \& Alshehri, 2013) have investigated the extent to which developed mathematics textbooks in the KSA are compatible with NCTM standards. Additionally, all researchers applied the analytical descriptive method to answer their research questions. The study samples were the content of the KSA developed mathematics textbooks.

The above table confirms that evaluating the contents of mathematics textbooks according to NCTM standards represents an important pillar in developing mathematics teaching and learning, particularly in the primary and intermediate stages in which the students' personalities are developed and their minds are opened to information not previously known, thereby preparing them and integrating them with the community, because many studies focus on mathematics books at the elementary stage such as the focus by Albalawi (2019) on the sixth grade; also the focus of Alshehr and Ali (2016) on the sixth grade six also the focus of Alzubi and Alobeidan (2014) on the fourth grade; and the focus of Hasanen and Alshehri (2013) on the third to fifth grades However, two studies focused on the middle stage (Altamimi, 2017) and part of a study sample (Alshehri \& Ali 2016). Furthermore, a study conducted by Alshehri (2015) focused on the secondary stage (first secondary). 
With regard to NCTM standards, both studies (Albalawi, 2019; Altamimi, 2017) covered all ten NCTM (2000) common standards; five process standards and five content ones. The process standards are: (1) problem solving, (2) reasoning and proof, (3) communication, (4) connections, and (5) representation. The content standards are: (1) number and operations, (2) algebra, (3) geometry, (4) measurement, and (5) data analysis and probability. The study conducted by Alshehri and Ali (2016) was limited to five areas of NCTM (2000) which are: number and operations, algebra, geometry, measurement, data analysis and probability. In their study, Alshehri (2015) covered only one area, namely number and operations. While the study conducted by Alzubi and Alobeidan (2014) was limited to the following six areas: number and operations, geometry, data analysis and probability, problem solving, reasoning and proof, and communication. The study undertaken by Hasanen and Alshehri (2013) was limited to five areas, namely: number and operations, algebra, geometry, measurement, and data analysis and probability.

As aforementioned, only the two studies conducted by Albalawi, (2019) and Altamimi (2017) covered all ten NCTM (2000) standards. Furthermore, other studies such as those conducted by Alshehri and Ali (2016) and by Hasanen and Alshehri (2013) were limited to five content standards. Studies conducted by Alshehri (2015) and Alzubi and Alobeidan (2014) were limited to one area and six areas respectively. It is important to mention that all studies which did not cover all ten areas of NCTM standards focused on content standards and not on process standards.

With regard to the results of all previous studies, we infer from studies Albalawi (2019) and Alshehri and Ali (2016) focused on the sixth grade developed mathematics textbook (primary stage). However, Albalawi (2019) focused on mathematics textbooks for the academic year 2017-2018 CE, and Alshehri and Ali (2016) focused on developed mathematics textbooks for the academic year 2013 -2014 CE. The results of the study conducted by Albalawi (2019) showed that the content of the developed mathematics textbook for the sixth grade in the KSA agrees with the standards of the content areas as follows: operation standards (47.63\%), algebra standards $(17.72 \%)$ and measurement standards (14.54\%). The percentage of the standards for data analysis and mathematical probability is 25.8 and the engineering standards 8.11 . The percentage of standards representation is $31.17 \%$; communication standards, $24.83 \%$; reasoning and proofing standards, 9.45\%; and that of problem-solving standards $8.72 \%$. The results of the study conducted by Alshehri and Ali (2016) revealed that the content of developed mathematics textbooks for grades 6 to 8 is $96.3 \%$ compatible with NCTM standards. We observe that the mathematics textbooks for the academic year 2017-2018 CE need to be reviewed, and we need to work on the standards of engineering, problem solving, reasoning and proof in order to conform to the standards. Furthermore, mathematics textbooks for the academic year 2013 to 2014 CE need to achieve the standards incompletely covered in the area of number and operations in order to achieve full compatibility. We notice the differences in the results in each academic year due to the continuous development in the curriculum by the Ministry of Education. Therefore, we need to search constantly to ensure that NCTM standards match the latest version of mathematics textbooks for Grade 6 . 
We now consider the studies conducted by Alzubi and Alobeidan (2014) and Hasanen and Alshehri (2013) which focused on the mathematics textbooks for the fourth and third to fifth grades respectively. Alzubi and Alobeidan (2014) focused on mathematics textbooks (fourth grade) for the academic year 2008 to 2009 CE.

Furthermore, Hasanen and Alshehri (2013) focused on the developed mathematics textbooks (third grade) for the academic year 2011 to 2012 CE. The results of the study conducted by Alzubi and Alobeidan (2014) revealed that the fourth grade mathematics textbook includes the following: numbers and the common operations $(2.03 \%$ $14.57 \%)$, geometry $(6.42 \%-13.58 \%)$, probability and analysis features $(6.98 \%-$ $15.12 \%)$, problem solving $(9.41 \%-28.24 \%)$, thinking and reasoning $(5.17 \%-15.52 \%)$, communication $(4.30 \%-25.81 \%)$. The results of the study conducted by Hasanen and Alshehri (2013) showed that the developed mathematics textbooks content for grades 3 to 5 in the KSA are $93.7 \%$ compatible with NCTM standards. We observed that the mathematics textbooks for the third, fourth and fifth grades need to achieve the standards incompletely covered.

The studies conducted by Altamimi (2017) and Alshehri and Ali (2016) focused on the middle stage mathematics textbook. Altamimi (2017) focused on the mathematics textbooks for the third grade of the middle stage for the academic year 2015 to 2016 CE. Moreover, Alshehri and Ali (2016) focused on the mathematics textbooks for the first and second grades of the middle stage for the academic year 2013 to $2014 \mathrm{CE}$. The results of the study conducted by Altamimi (2017) showed that standard mathematical connections had a degree of consistency with the average. Moreover, the results of the study conducted by Alshehri and Ali (2016) revealed that the content of developed mathematics textbooks for grades 7 and 8 is $96.3 \%$ compatible with NCTM standards. We observe that the mathematics textbooks for the first, second and third grades of the middle stages need to achieve the standards incompletely covered.

The study conducted by Alshehri (2015) focused on the mathematics textbook for the first grade of the secondary stage in the KSA for the academic year 2014 to 2015 CE. The results showed that the realisation of NCTM standards in the first secondary mathematics textbook content is very low, in which the percentage does not exceed 13 which is educationally unacceptable. We observe that the percentage is very low, thereby indicating that the stakeholder needs to review the curriculum in order to satisfy the standards, because in the secondary stage, an important part of the study will begin to consider the future career. This means that the learning experiences of this stage of education becomes important for their future career. Furthermore, we should not forget that this stage is the bridge between school and university. Therefore, the curriculum should include all NCTM standards in order to improve learning outcomes and student achievement in mathematics.

We consider it essential to address "To what extent the developed mathematics textbooks in the KSA are compatible with NCTM standards", particularly the first and second grades of the primary stage and the second and third grades of secondary stage. The reason for this is that no research has located any study covering these grades so far. However, we need such studies because many previous researchers have investigated 
mathematics programmes based on NCTM standards (Ardisana, 2006; Blackwell, 2001; Heitmann, 2006; Jitendra et al., 2010; Wood, 2006). These previous researchers found a positive relationship between learning outcomes and achievement of students in mathematics based on the design of the textbooks' compliance to NCTM standards.

However, we recommend the researchers to investigate all developed mathematics textbooks in all grades in the KSA to test for their compatibility with NCTM standards because we need studies that focus on the developed mathematics textbooks for the academic year 2018 to 2019 CE. Furthermore, regarding the literature review section; although the principal focus of Vision 2030 is in the direction of several business investment enterprises, cultural programmes and economic reforms, it is impossible to introduce such programmes without there being quality education. Therefore, the researchers and stakeholders should ensure that these curricula are aligned to the vision which will happen if all new mathematics is compliant with global standards, particularly NCTM standards.

We are aware that mathematics is at the basis of both science and technology, and that the standard of economic and social advance has a close association with the developmental level in mathematical sciences (Kuku, 2012). Affirmation has emerged of the cause of the gap in the developmental level between developing and advanced nations is the gap in the standard of teaching and learning in mathematics (Ukeje, 2002). In Saudi, there is a gap between the skills which students acquire and the current necessities of life and work. Education ought to be reconstructed in order to satisfy the goals of Vision 2030 (Almaimooni, 2016).

Therefore, in order to reduce the gap, the stakeholder should revise all mathematics curricula to ensure that they include both categories of standards (NCTM, 2000; namely content and process standards as follows: (1) problem solving, (2) reasoning and proof, (3) communication, (4) connections, (5) representation, (6) number and operations, (7) algebra, (8) geometry, (9) measurement, and (10) data analysis and probability.

We know that having good and strong problem-solving skills can make a tremendous difference to lives and careers in the future. Reasoning and proof should be a consistent part of a student's mathematical experience from pre-kindergarten to Grade 12, because the ability to reason enables students to use mathematical knowledge to generate and solidify mathematical ideas that are new to them. Communication skills that students learn can now be of benefit to them in the future. Connections are important because many students have difficulty in connecting mathematical knowledge to real life. Moreover, representation serves the bridge role for students to understand and express mathematical ideas. Number and operations play an important role in students' lives and careers, and almost all of our activities involve numbers and mathematics. Algebra reinforces logical thinking, whereas geometry is important because the world comprises different shapes and spaces. Measurement is important because it helps us to quantify the world around us. With regard to data analysis and probability, we live in an information world and much of this information is determined mathematically by statistical help. 
Consequently, we can find that all the meaning of the ten standards which we need in order to satisfy the vision of Kingdom 2030; therefore, we hope that when developing mathematics books, they will include NCTM standards which will give an opportunity for researchers to not consider "to what extent are the developed mathematics textbooks in the KSA compatible with NCTM standards".

\section{CONCLUSION}

International studies showed that textbooks affect students' attainment in mathematics, so many researchers have compared the textbooks of different countries and they analyzed the content of textbooks. The evaluation of mathematics textbook content for grades 3 to 10, according to NCTM standards in Saudi, has been addressed previously by a number of researchers (Albalawi, 2019; Altamimi, 2017; Alshehri \& Ali, 2016; Alshehri, 2015; Alzubi \& Alobeidan, 2014; Hasanen \& Alshehri, 2013). They all recommended achieving the standards not completely covered in specific areas of mathematics in order to achieve complete compatibility, and to enhance teacher training enabling the teaching of the newly- developed curriculum appropriately, in order to achieve global standards of quality in the educational process. Furthermore, they recommend conducting a study to evaluate the content of developed mathematics for grades that were not covered in their studies. We found that the mathematics curriculum for the first grade of the secondary stage in particular achieved a low percentage of NCTM standards.

\section{RECOMMENDATIONS}

1- International studies showed that textbooks affect students' attainment in mathematics, so further studies should be conducted to evaluate the content of developed mathematics for grades 1 to 12 in other countries which perform well in mathematics.

2- Each of the textbooks used in KSA should be reviewed to enrich the content and process standards and focus on the NCTM standards incompletely covered. In particular these aspects need attention:

a. Primary Fourth grade: analysis of patterns for functions using vocabulary, understanding and applying basic concepts in probability which support students to use scientific methods of proof and helps them to communicate mathematical ideas to their peers clearly. It also helps to identify stoichiometric shapes and to describe combinations numbers according to their natural characteristics.

b. Primary Sixth grade: to enrich content standards and focus on the standards of numbers and operations and those of engineering. In addition all of the process standards and the standards relating to problem solving, reasoning and proof, in order to keep abreast with international developments.

c. Middle stage first and second grades: ensure effective coverage of the standards, especially number and operations. 
d. Middle stage third grade: ensure effective coverage of the standards, especially mathematical communication

e. Secondary first grade: Number and operations.

3- Researchers should conduct a study to evaluate the content of mathematics for Grades 1 to 12 with NCTM standards to ensure that the current mathematics curriculum aligns the KSA Vision 2030, with NCTM (2000) standards to ensure vision objectives can be achieved.

\section{ACKNOWLEDGEMENT}

We would like to thank God Almighty for giving us the strength, knowledge, ability and opportunity to undertake this research study.

\section{REFERENCES}

Abdul Salam, M. A. (2006). Developing the Educational Curriculum to Fulfill the Requirements of Development and Meet the Challenges of Globalization. A Research Presented to the Conference of Qualitative Education and its Role in Human Development in the Era of Globalization, the 1st Scientific Conference of the Faculty of Special Education, Mansoura University on April, 12-13, 271-310.

Abbas, K., \& Alabsi, M. (2007). Curriculum and methods of teaching mathematics to basic minimum phase. Dar Almasirah for publishing, distribution and printing, Oman, Jordan.

Ardisana, V. (2006). Standards-Based Mathematics Strategies for the Improvement of Academic Language A Quasi -Experimental Study. Ph.D. College of Education, Northern Arizona University.

Albalawi, A. (2019). The Compatibility of the Content of the Mathematics Textbook for the Sixth Grade in Saudi Arabia with the Standards of the National Council of Teachers of Mathematics (NCTM). Shaqra University Journal, 11. Retrieved from http://portal.su.edu.sa/sites/default/files/2019

Almaimooni, M. (2016). A one trillion riyal non-oil revenue approaching: Deputy crown prince reveals 13 national initiatives for Kingdom's future Vision 2030. AlYaum Newspaper. Retrieved from http://www.alyaum.com/article/4133366

Alshehri, A. A. A. (2015). Evaluating the content of mathematics textbook for the first grade secondary in Saudi Arabia in the light of standards (NCTM). Journal of Arab studies in education and Psychology, 63, 191-220. Retrieved from http://search. mandumah. com/ Record /70 0617

Alshehri, M. A., \& Ali, H. S. (2016). The Compatibility of Developed Mathematics Textbooks' Content in Saudi Arabia (Grades 6-8) with NCTM Standards. Journal of Education and Practice, 7(2), 137-142.

Altamimi, A. (2017). The consistency of the third grade of middle school mathematics book in Saudi Arabia with Global Standards for Operations and Content (NCTM, 2000). 
International Interdisciplinary Journal of Education, 6(3), 160-170. Retrieved from http://iijoe.org/v6/IIJOE_12_03_06_2017.pdf

Alzubi, A., \& Alobeidan, A. (2014). An analysis of the mathematics textbook of the fourth grade with respect to the NCTM standards. Dirasat: Educational Sciences, 41(1), 317-331. Retrieved from http://search.mandumah.com/Record/605784

Alzahrani, A. K. (2017). Markets and language policy in Saudi Arabia: how the English language can contribute to the success of the Saudi vision 2030. International Journal of English Language and Linguistics Research, 5(6), 1-12. Retrieved from https://www.eajournals.org

Ball, D. L., \& Feiman-Nemser, S. (1988). Using textbooks and teachers' guides: A dilemma for beginning teachers and teacher educators. Curriculum Inquiry, 18 (4), 401423.

Blackwell, M. (2001). Analysis of the 1998 Mathematics Framework for California Public School: Comparisons to Student Performance, Standardized, Test Objectives, and the NCTM Principle and Standards for School Mathematics. Ph.D. Teachers College, Columbia University.

Chiappetta, E., \& Fillman, D. (2007). Analysis of five high school biology textbooks used in the United States for inclusion of the nature of Science. International Journal of Science Education, 29, 847-868.

Dixon-Woods, M. (2010). Systematic reviews and qualitative methods. In Silverman, D. (ed.) Qualitative research: theory, method and practice. 3rd ed. London: Sage, pp. 331346.

Foxman, D. (1999). Mathematics textbooks across the world: Some evidence from the third international mathematics and science study. Slough: National Federation for Educational Research.

Freeman, D. J., \& Porter, A. C. (1989). Do textbooks dictate the content of mathematics instruction in elementary schools? American Educational Research Journal, 26(3), 403421.

Fujita, T., \& Jones, K. (2003). The place of experimental tasks in geometry teaching: Learning from the textbooks design of the early 20th Century. Research in Mathematics Education, 5(1), 47-62. Retrieved from https://doi.10.1080/14794800008520114

Ginsburg, A., \& Leinwand, S. (2005). Singapore math: Can it help close the U.S mathematics learning gap? Presented at CSMC's First International Conference on Mathematics Curriculum, November 11-13.

Haggarty, L., \& Pepin, B. (2002). An investigation of mathematics textbooks and their use in English, French, and German classrooms: who gets an opportunity to learn what? British Educational Research Journal, 28(4), 567-590. 
Hasanen, H. S., \& Alshehri, M, A. (2013). Assessing the content of developed mathematics textbook for the primary school in Saudi Arabia in the light of the NCTM standards. Mathematics education Journal, 16 (2), 6-29.

Heitmann, L. (2006). Implementing the New York State Learning Standards in Mathematics Professional, Development, Instructional Leadership, and Student Learning. Ph.D. College of Education, Fordham University, New York.

Higgins, J., \& Green, S. (2009). Cochrane handbook for systematic reviews of interventions. London: The Cochrane Collaboration.

Jitendra, A., Griffin, C., \& Xin, Y.P. (2010). An evaluation of the intended and implemented curricula's adherence to the NCTM standards on mathematics achievement of third grade students: A case study. Journal of Curriculum \& Instruction, 4(2), 33-50. doi; 10.3776/joci.2010.v4n2p33-50.

Johansson, M. (2003). Textbooks in mathematics education: a study of textbooks as the potentially implemented curriculum (Licentiate thesis). Lulea: Department of Mathematics, Lulea University of Technology.

Johansson, M. (2005). Mathematics textbooks - the link between the intended and the implemented curriculum. Paper presented to - the Mathematics Education into the 21st Century Projectl Universiti Teknologi, Malaysia. Retrieved from http://math.unipa.it/ grim/21_project/21_malasya_Johansson119-123_05.pdf

Keith, S. (1991). The Determinants of Textbook Content. In P. G. Altbach, G. P. Kelly, H. G. Petrie, \& L. Weis (Eds.), textbooks in American society (pp. 43-60). Albany: State University of New York Press.

Kuku, A. O. (2012). Mathematics as a time-tested resource for scientific, technological, socioeconomic and intellectual development. Ibadan: Ibadan University Press.

$\mathrm{Li}, \mathrm{Y}$. (1999). An analysis of algebra content, content organization and presentation, and to-be-solved problems in eighth-grade mathematics textbooks from Hong Kong, Mainland China, Singapore, and the United States. Doctoral dissertation, University of Pittsburg. (UMI: AAT 9957757).

Li, Y. (2000). A comparison of problems that follow selected content presentation in American and Chinese mathematics textbooks. Journal for Research in Mathematical Education, 31, 234-241.

Lo, J. J., Cai, J., \& Watanabe, T. (2001). A comparative study of the selected textbook from China, Japan, Taiwan and the United States on the teaching of ratio and proportion concepts (Reports - Research Speeches/Meeting Papers)

Mayer, R.E., Sims, V., \& Tajika, H. (1995). A comparison of how textbooks teach mathematical problem solving in Japan and the United States. American Educational Research Journal, 32, 443-460. 
Mrayyan, S. (2013). Jordanian elementary math curriculum and geometry content along with National Council Teachers of Mathematics (NCTM) grades (1-6) as case study. Greener Journal of Educational, 3(3), 144-154.

Mundy, J. (2000). Principles and standards for school mathematics: A guide for mathematicians. Notices Of the AMS, 47(8), 868-876.

National Council of Teachers of Mathematics. (2000). Principles and Standards for School Mathematics. Reston, VA.

Nicol, C. C., \& Crespo, S. M. (2006). Learning to teach with mathematics textbooks: How pre-service teachers interpret and use curriculum materials. Educational Studies in Mathematics, 62(3), 331-355.

Obeid, W. (2010). Mathematics education for all children. Dar Almasirah for publishing, distribution and printing. Aman, Jordan.

Olkun, S., \& Toluk, Z. (2002). Textbooks, word problems, and student success on addition and subtraction. International Journal of Mathematics Teaching and Learning. Retrieved from http://www.cimt.plymouth.ac.uk/journal/default.htm

Pepin, B. (2001). Mathematics textbooks and their use in English, French and German classrooms: a way to understand teaching and learning cultures. Zentralblatt fuer Didaktik der Mathematik, 33(5), 158-175.

Reys, B., Reys, R., \& Chávez, O. (2004). Why mathematics textbooks matter. Educational Leadership, 61(5), 61-66.

Santos, D., Macias, G., Cruz, J. (2006), Expectations vs. Reality of the Use of Mathematics Textbooks in Elementary Schools, Paper presented at the annual meeting of the North American Chapter of the International Group for the Psychology of Mathematics Education, TBA, Merida, Yucatan, Mexico. Retrieved from http://www.allacademic.com/meta/p115348_index.html

Saeed, R., Abdul Hamid, A., \& Alshalhoub, S. (2011). Matrix of scope \& sequence of mathematics for grades (1-8) according to the McGraw-Hill series in Saudi Arabia (Analytical study). The eleventh Conference of the Association of mathematics education, reality of teaching and learning of mathematics education: problems and solutions and future visions - Ain Shams University, July 19, pp 52-86.

Saudi Arabia's Vision for 2030. (2017). Education. Retrieved from http:/ / vision 2030.gov.sa/ar/node/188

Schmidt, W. H., McKnight, C. C., Valverde, G. A., Houang, R. T., \& Wiley, D. E. (1997). Many visions, many aims: a cross-national investigation of curricular intentions in school mathematics (Vol. 1). Dordrecht: Kluwer.

Schmidt, W. H., McKnight, C. C., Houang, R. T., Wang, H., Wiley, D. E., Cogan, L. S., et al. (2001). Why schools matter: a cross-national comparison of curriculum and learning. San Francisco: Jossey-Bass. 
Schmidt, W., Houang, R., \& Cogan, L. (2002). A coherent curriculum: the case of mathematics. American Educator, 26(2), 10-26, 47.

Stevenson, H. (1985). An analysis of Japanese and American textbooks in mathematics. Office of Educational Research and Improvement (ed.). Washington, DC (clearing house no. SO017450).

Stigler, J. W., Fuson, K. C., \& Ham, M. S. (1986). An analysis of addition and subtraction word problems in American and Soviet elementary mathematics textbook. Cognition and Instruction, 3, 153-171.

Tyson, H., \& Woodward, A. (1989). Why students aren't learning very much from textbooks. Educational Leadership, 47(3), 14-17.

Törnroos, J. (2004). Mathematics textbooks, opportunity to learn and achievement. Retrieved from http://www.icme-organisers.dk/dg14/DG14-Jukka.pdf

Ukeje, B.O. (2002). Production and retention of mathematical sciences teachers for Nigerian educational system. In S. O. Ale \& L. O. Adetula (Eds) (2005), Reflective and Intellectual Position papers on mathematics Education Issues pp 80-102. Abuja; Marvelous Mike Nigeria Ltd.

Valverde, G. A., Bianchi, L. J., Wolfe, R. G., Schmidt, W. H., \& Houang, R. T. (2002). According to the book: Using TIMSS to investigate the translation of policy into practice through the world of textbook. Dordrecht; Boston: Kluwer Academic Publishers.

Wood, F. (2006). The Relationship Between the Measured Changes in the Mathematics Scores of Eighth Grade New Jersey Students and The Implementation of StandardsBased Mathematics Program. Ph.D. Faculty of the School of Human Service Professions, Widener University.

Yeap, B. H. (2005). Building foundations and developing creativity: An analysis of Singapore mathematics textbooks. Paper presented at the Third East Asia Regional Conference on Mathematics Education in Shanghai, China.

Zhu, Y., \& Fan, L. (2004). An analysis of the representation of problem types in Chinese and US mathematics textbooks. Paper accepted for ICME-10 Discussion Group 14, 4-11 July: Copenhagen, Denmark. 